\title{
CONTROL OF COOLING WATER STABILITY WITH RESPECT TO CARBONATE DEPOSITS
}

\author{
V. Z. Kochmarskii
}

Physical and Technological Laboratory of Water Systems of the National University of Water and Environmental Engineering, Rivne, Ukraine

Corresponding author: v.z.kochmarskii@nuwm.edu.ua

\begin{abstract}
It is shown that according to the analysis of deposits on the condensers of 22 power plants the main component of deposits is calcium carbonate. Magnesite is practically not available in the deposits. $\mathrm{Mg}^{2+}$ ions in circulating water behave like chlorides being concentrated during evaporation. Note that the existing methods for determining the stability of cooling water (CW) provide only qualitative information about its stability. They rely on the use of total hardness and give incorrect stability values. The method for the quantitative determination of the degree of CW stability is suggested, which is based on measurements of the concentration of $\mathrm{Ca}^{2+}$ ions in the $\mathrm{CW}$ and in the feed water and on the determination of the degree of concentration of salts in the CW. Based on these parameters, the $\mathrm{CW}$ stability index is calculated in relation to $\mathrm{CaCO}_{3}$ formation. Having current values of the stability index, it is proposed to promptly develop and correct measures to achieve the required level of CW stability, for example, to determine the value of acidification or blowing of the circulating cooling system which is sufficient for achieving an expected degree of stability.
\end{abstract}

Keywords: cooling water; deposits; stability index; calcium carbonate; stability correction.

\section{Introduction}

Circulating cooling systems (CCS) are the most efficient elements of water supply technology for thermal and nuclear power plants (Shabalin, 1972; Kucherenko, 1980; Kochmarskii and Pospelov, 1986; Andronov, 2004; Gayevskii and Kochmarskii, 2018) on the rational use of water and reduction of chemical and thermal pollution of the water basin. However, due to the evaporation of water and the associated concentration of salts, as well as the heterogeneous hydrodynamic regime 
in water mains and coolers, CCS have specific operational problems (Kochmarskii and Pospelov, 1986; Gayevskii and Kochmarskii, 2018):

1) carbonate, sulfate and silicate deposits on heat exchange surfaces and water mains due to the concentration of the relevant components;

2) fouling of structural elements by fungi, microscopic algae and dreisen - the result of increased temperature of cooling water $(\mathrm{CW})$;

3) mechanical deposits of dispersions in hydrodynamically stagnant zones.

Since surface waters, which are mainly calcium-carbonate systems (CCS), are most often used for cooling, the main contaminants of heat exchange surfaces are the deposition of low soluble salts such as $\mathrm{CaCO}_{3}$. Fig. 1 and (Kochmarskii and Pospelov, 1986).

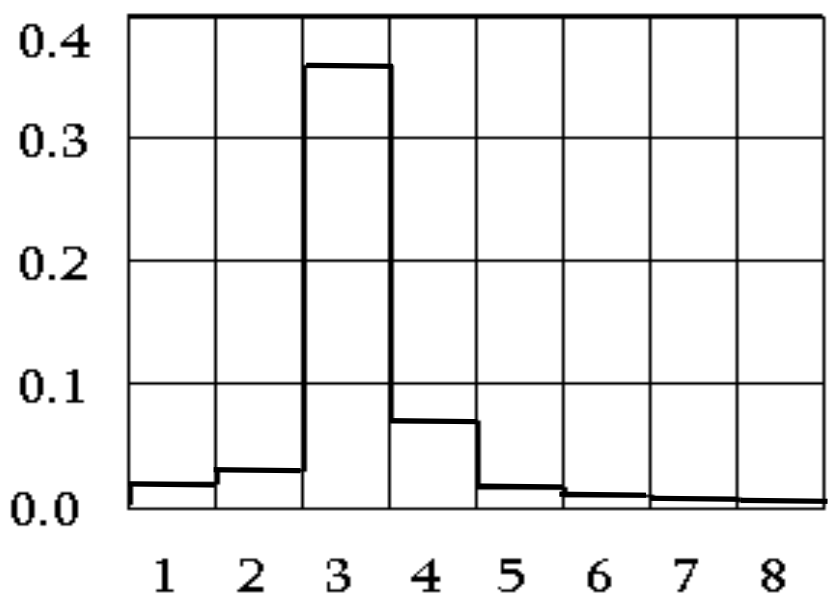

Fig. 1. Relative composition of deposits on the tubes of condensers by the data of 22 power plants (Kochmarskii and Pospelov, 1986): $1-\mathrm{SiO}_{2}, 2-\mathrm{Fe}_{2} \mathrm{O}_{3}, 3-\mathrm{CaCO}_{3}, 4$ - organic compounds, 5 $\mathrm{MgCO}_{3}, 6-\mathrm{CaSO}_{4}, 7-\mathrm{CaO}, 8-\mathrm{P}_{2} \mathrm{O}_{5}$.

Deposits reduce the efficiency of heat exchangers (HE), as well as other equipment due to the reduction of their heat transfer coefficient, increasing the hydraulic resistance of networks and increasing energy consumption for their operation. In addition, pitting corrosion occurs under the deposits in the pipe systems (PS), which, for example, at nuclear power plants has led to the need to replace steam generators. Because of deposits their life cycle was reduced from 30-40 to 10-15 years.

\section{Analysis of the existing situation and problem statement}

Deposits, in particular carbonate, occur due to the deviation of the state of $\mathrm{CW}$ from equilibrium, i.e. its instability. Today, the SI supersaturation index relative to calcium carbonate SI and the 
Langelier LI index are used to characterize the state of CW relative to deposits (Alekin, 1970; RD 34.37.307-87. SPO Soyuztekhenergo, 1989; State Building Code (SBC) V.2.5-74: 2013)

$$
\mathrm{SI}=\frac{\mathrm{K}_{1}(\mathrm{t}) \cdot \mathrm{K}_{2}(\mathrm{t})}{\mathrm{L}_{\mathrm{CaCO}_{3}}} \cdot \frac{\left(\mathrm{Ca}^{2+}\right) \cdot\left(\mathrm{CO}_{2}\right)}{10^{-2 \mathrm{pH}}}, \quad \mathrm{LSI}=-\mathrm{Log}\left[\frac{\left(\mathrm{H}^{+}\right)}{\left(\mathrm{H}_{\mathrm{st}}^{+}\right)}\right]=\mathrm{pH}-\mathrm{pH}_{\mathrm{st}},
$$

$\mathrm{K}_{1}, \mathrm{~K}_{2}$ - thermodynamic constants of dissociation of carbonic acid of the first and second degrees, activity of the corresponding ions, g-ion $/ \mathrm{dm}^{3},\left(\mathrm{H}_{\mathrm{st}}\right),(\mathrm{H})$ - activity of hydrogen ions corresponding to the equilibrium (stable) and current state of $\mathrm{CW} ; \mathrm{L}_{\mathrm{CaCO}}$ is the product of the solubility of $\mathrm{CaCO}_{3}$. It is the indices (1) that are recommended to be used to characterize the stability of $\mathrm{CW}$ in the guiding documents on the operation of CCS and industry standards, for example, (RD 34.37.30787. SPO Soyuztekhenergo, 1989). According to (1) CW is considered stable when SI $\approx 1$, and the Langelier index LSI $<0.3$.

To get acquainted with the situation in the real circulating waters of the CCS, we calculated the values (1) for the CW of one of the power plants of Ukraine. see Fig. 2.

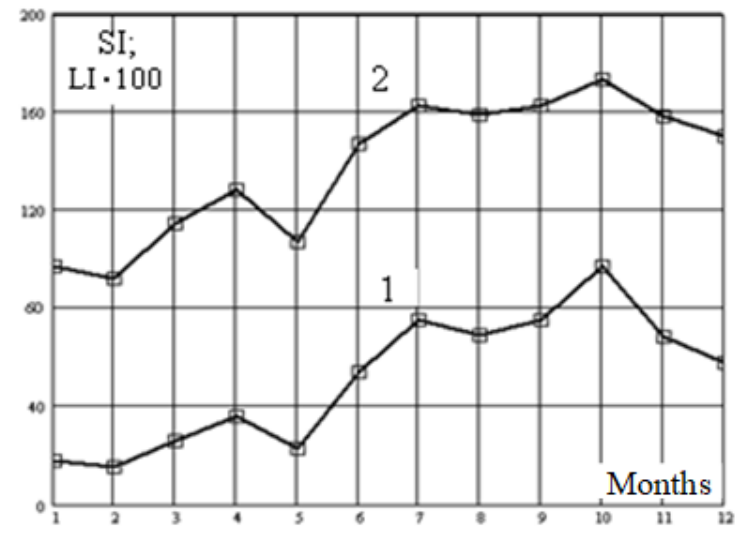

Fig. 2. Dependence of supersaturation indices (SI), curve 1 and Langelier (LI), curve 2, on the number of the month. For convenience, the value of LI is increased by 100 times.

Both indices show values that are an order of magnitude larger than the standard values: $\mathrm{SI} \approx 1$, and the LSI $<0.3$. Their values are the greatest in the period from the 5 th to the 11 th month. It would seem (if we follow the standard interpretation of the data in Fig. 2) that the ability of CW to form solid $\mathrm{CaCO}_{3}$ is the greatest during this period. But it is impossible to judge the $\mathbf{C W}$ stability value by the data of (1). It is necessary to interpret correctly the calculations data by (1), especially in the conditions of application of deposits inhibitors. The values of the indices (1) depend on the concentration of $\mathrm{Ca}^{2+}$ ions and bound carbon dioxide, and they can be important due to the fact that deposit inhibitors keep these parameters in the ionic state, giving the false impression of deep CW instability, i.e. its ability to deposition. 
In order to develop effective measures for removing deposits we need quantitative characteristics of the degree of stability of $\mathrm{CW}$, which could be determined on the basis of standard measurements performed during the operation of CCS.

Therefore, the task of determining the quantitative degree of stability of $\mathrm{CW}$ is a pressing one in the operation of CCS and related heat exchange equipment, and it is the development of quantitative methods for determining the stability of CW that this work considers.

\section{Control of CW stability}

In order to develop effective measures for reducing the growth rate of deposits, it is necessary to have a quantitative characteristics of the stability of CW. This problem was studied in the Physical and Technological Laboratory of Water Systems (Kochmarskii and Kochmarskii, 2009; Pat. UA 114060, 2017; Pat. UA 128018; Kochmarskii and all, 2017), where for laboratory conditions we developed the method of quantitative determination of CW stability based on the evaporation of $\mathrm{CW}$ sample at a temperature of $(60-70)^{\circ} \mathrm{C}$, which is characterized by the stability index,

$$
\mathrm{StI}=\frac{\mathrm{C}_{\mathrm{Ca}}(\mathrm{t})}{\mathrm{C}_{\mathrm{Ca}}(0) \cdot \mathrm{k}_{\text {вп }}(\mathrm{t})} ; \operatorname{PrI}=1-\frac{\mathrm{C}_{\mathrm{Ca}}(\mathrm{t})}{\mathrm{C}_{\mathrm{Ca}}(0) \cdot \mathrm{k}_{\text {вп }}(\mathrm{t})}=1-\mathrm{StI}
$$

StI - water stability index, $\mathrm{PrI}$ - deposit index (instability); $\mathrm{C}_{\mathrm{Ca}}(\mathrm{t}), \mathrm{C}_{\mathrm{Ca}}(0)$, - respectively, the concentration of calcium ions at time $t$ and at the initial moment $t=0 ; k_{e v}(t)$ - water evaporation coefficient, $\mathrm{k}_{\mathrm{ev}}(\mathrm{t})=\mathrm{V}(0) / \mathrm{V}(\mathrm{t}) ; \mathrm{V}(0), \mathrm{V}(\mathrm{t})$ is the initial volume of the water sample and at time $\mathrm{t}$. It is obvious, that both Sti and PrI indices are interrelated, see (2)

$$
\text { Sti }+\operatorname{PrI}=1 .
$$

For circulating CCS water, the operative value of the stability index is determined similarly to (2), only the content of concentrations in formula (2) is different (Kochmarskii and Kochmarskii, 2009; Pat. UA 114060, 2017),

$$
\operatorname{StI}(\mathrm{t})=\frac{\mathrm{C}_{\mathrm{Ca}}(\mathrm{t})}{\mathrm{C}_{\mathrm{Ca} 0}(\mathrm{t}) \cdot \mathrm{k}(\mathrm{t})} \rightarrow \mathrm{k}(\mathrm{t})=\frac{\mathrm{C}_{\mathrm{Cl}}(\mathrm{t})}{\mathrm{C}_{\mathrm{Cl} 0}(\mathrm{t})} \rightarrow \frac{\mathrm{C}_{\mathrm{Ca}}(\mathrm{t})}{\mathrm{C}_{\mathrm{Ca} 0}(\mathrm{t})} \cdot \frac{\mathrm{C}_{\mathrm{Cl} 0}(\mathrm{t})}{\mathrm{C}_{\mathrm{Cl}}(\mathrm{t})}
$$

$\mathrm{C}_{\mathrm{Ca}}(\mathrm{t}), \mathrm{C}_{\mathrm{Cl}}(\mathrm{t})$ - respectively, the concentration of calcium ions and chlorides in $\mathrm{CW}$ at time $\mathrm{t}$; $\mathrm{C}_{\mathrm{Ca} 0}(\mathrm{t}), \mathrm{C}_{\mathrm{Cl0}}(\mathrm{t})$ - the same concentrations in the feed water of CCS at the same time.

The stability index can be expressed by the CCS mode of operation. To do this, we use the relationship between the concentration coefficient of salts $\mathrm{k}$ and water consumption for feeding $\mathrm{G}_{\mathrm{f}}$ and blowing $\mathrm{G}_{\mathrm{b}}$ (Gayevskii and Kochmarskii, 2018), which is valid under conditions of stability of CCS water volume,

$$
k(t)=\frac{G_{f}(t)}{G_{b}(t)} \text {, consequently: } \operatorname{StI}(t)=\frac{C_{C a}(t)}{C_{C a 0}(t) \cdot k(t)} \rightarrow \frac{C_{C a}(t)}{C_{C a 0}(t)} \cdot \frac{G_{b}(t)}{G_{f}(t)} .
$$


Expression (5) allows us to determine the value of blow, which provides a expected stability of $\mathrm{CW}(\mathrm{StI}$ value $)$,

$$
\mathrm{G}_{\mathrm{b}}(\mathrm{t})=\operatorname{StI}(\mathrm{t}) \cdot \mathrm{G}_{\mathrm{f}}(\mathrm{t}) \cdot \frac{\mathrm{C}_{\mathrm{Ca} 0}(\mathrm{t})}{\mathrm{C}_{\mathrm{Ca}}(\mathrm{t})}
$$

$\mathrm{G}_{\mathrm{b}}(\mathrm{t}), \mathrm{G}_{\mathrm{f}}(\mathrm{t})$ - blow and feeding water discharge respectively.

Note that Regulations for nuclear and thermal power plants (RD 34.37.307-87. SPO Soyuztekhenergo, 1989; State Building Code (SBC) V.2.5-74: 2013) recommend to determine the stability of $\mathrm{CW}$ by using hardness but not concentrations of calcium ions. Remember that the hardness of water $\mathrm{J}$ is the sum of the concentrations of calcium and magnesium ions,

$$
\mathrm{J}=\mathrm{C}_{\mathrm{Ca}}+\mathrm{C}_{\mathrm{CMg}} \text {. }
$$

However, magnesite $\mathrm{MgCO}_{3}$ has a solubility greater than calcite $\mathrm{CaCO}_{3}$ approximately 250-300 times and in the process of salts concentration during the operation of CCS under the same conditions it practically does not form solid deposits, see also Fig.1. Therefore, $\mathrm{Mg}^{2+}$ ions are concentrated in CW like chlorides and do not form deposits. This can be seen in Fig. 3 where according to the data for $\mathrm{CW}$ that corresponds to fig. 2 the concentration coefficients by magnesium $\mathrm{k}_{\mathrm{Mg}}$ and chlorides $\mathrm{k}_{\mathrm{Cl}}$ are shown.

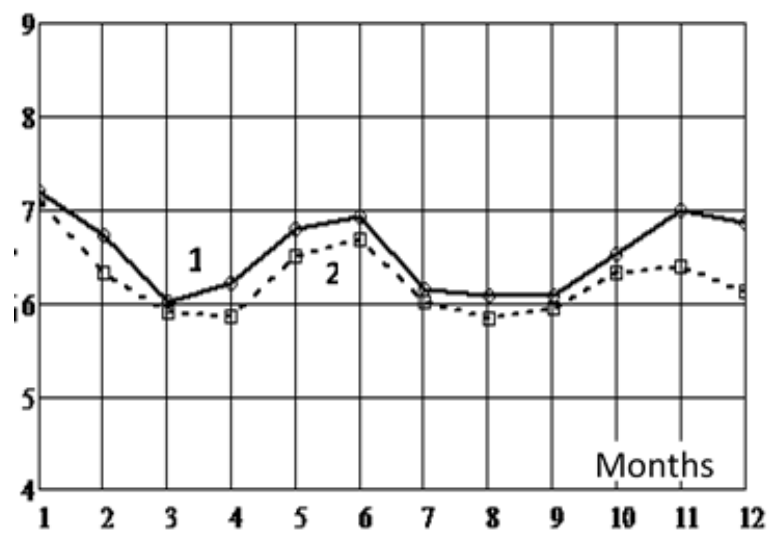

Fig. 3. Dependences of salt concentration coefficients by chlorides $\mathrm{kCl}$ - curve 1, by magnesium $\mathrm{kMg}$ - curve 2 on the number of the month.

A slight difference between the values of $\mathrm{k}_{\mathrm{Cl}}$ and $\mathrm{k}_{\mathrm{Mg}}$ is within the measurement error. The values of StI $\mathrm{Ca}_{\mathrm{a}}$ by (4) and determined by the total hardness of $\mathrm{St}_{\mathrm{IJ}}$ (7) in accordance with the data of Fig. 2, are shown in Fig. 4. We see that the determination of the stability of the $\mathrm{CW}$ in terms of hardness overestimates the real stability by (25-45)\% and disorients the operating personnel.

Compare the data for the curves 1 of Fig. 2 and 4. We see their symbatic behavior, which indicates the already mentioned feature of the mode of application of deposits inhibitors, which hold $\mathrm{Ca}^{2+}$ ions in solution and thus create the impression of high supersaturating of CW. From the standpoint 
of the definition of StI, it is clear that high concentration of $\mathrm{Ca}^{2+}$ ions in $\mathrm{CW}$ corresponds to their absence in solid forms that form deposits. Thus, high saturation or Langelier indices are more likely to indicate the use of deposits inhibitors, which contain the corresponding substances in ionic or molecular forms and, conversely, stabilize water. Note that the latter is not always realized by operating personnel and researchers.

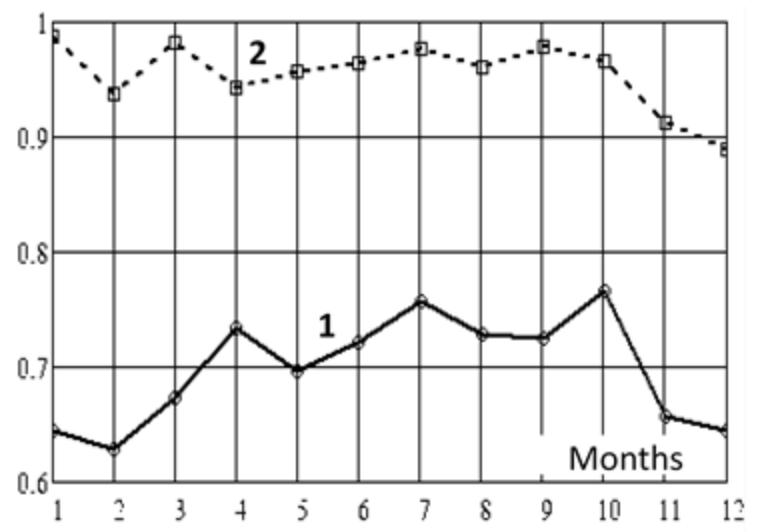

Fig. 4. Dependences of $\operatorname{StI}_{\mathrm{Ca}}$, according to formula (4), curve 1 and $\mathrm{StI}_{\mathrm{J}}$ - curve 2 on the month number.

There is another advantage of using the stability index, even with the correct interpretation of the value of saturation index. In fact, curve 1 in Fig. 4 indicates that the CW stability in the first half of the year was not higher than $73 \%$, and in general it did not exceed $75 \%$. This means that in November-February only $65 \%$ of $\mathrm{Ca}^{2+}$ ions were in solution, and $35 \%$ was released in a solid form capable of forming deposits. Therefore, stabilization of CW during this period was insufficient and additional stabilization measures would be required, such as acidification of $\mathrm{CW}$ with strong acids, in particular sulfuric acid, or adjustment of blow according to (6).

The acid concentration can be determined by using (4). To do this, take into account that each gram-ion of acid binds an equivalent amount of calcium ions, i.e. the concentration of acid Ck, which must be in circulating water is determined by the formula

$$
\mathrm{C}_{\mathrm{K}}(\mathrm{t})=\mathrm{k} \cdot \mathrm{C}_{\mathrm{Ca} 0}(\mathrm{t}) \cdot[\max \mathrm{StI}-\mathrm{StI}(\mathrm{t})],
$$

and in feed water, respectively,

$$
\mathrm{C}_{\mathrm{K} 0}(\mathrm{t})=\mathrm{C}_{\mathrm{Ca} 0}(\mathrm{t}) \cdot[\max \operatorname{StI}-\operatorname{StI}(\mathrm{t})] \text {. }
$$

maxStI is the maximum (desired by the station personnel) $\mathrm{CW}$ stability index.

Taking, for example, maxStI $=0.9$ according to Fig. 4, curve 1, the required concentration of $100 \%$ $\mathrm{H}_{2} \mathrm{SO}_{4}$ in the feed water is calculated, which is sufficient to increase the stability of $\mathrm{CW}$ from the existing curve 1 in Fig. 4, to a value of 0.9 (90\%). The result of the calculation is shown in Fig. 5. 
We see that the acid concentration varies depending on the current CW stability in the range from 8 to $17 \mathrm{~g} / \mathrm{m}^{3}$. Therefore, using the suggested method of determining the stability of $\mathrm{CW}$, you can quickly adjust the dosage of inhibitors and acids for acidification of $\mathrm{CW}$, avoid overconsumption of reagents and excessive environmental pollution.

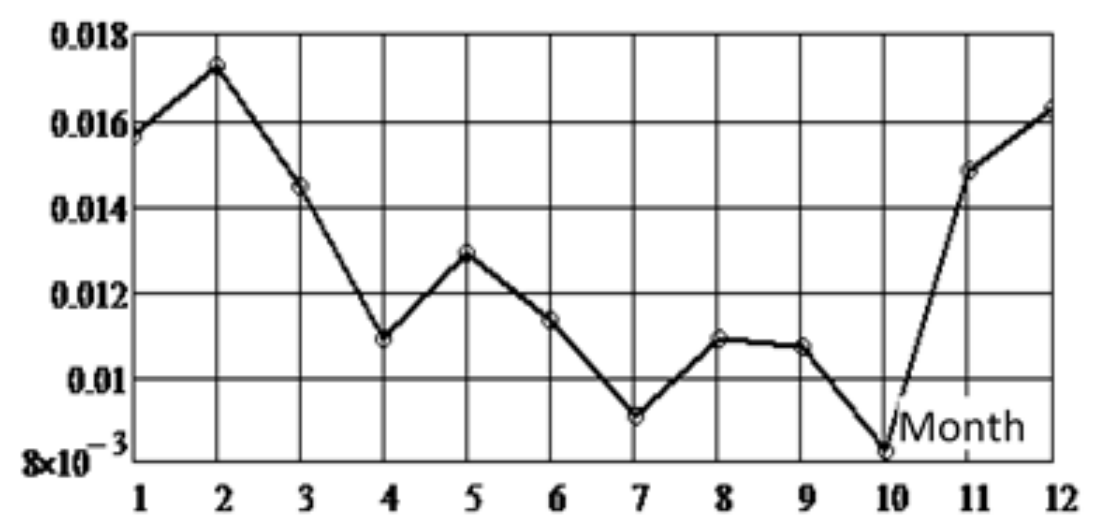

Fig. 5. Dependence of the concentration of $\mathrm{H}_{2} \mathrm{SO}_{4}$ acid (100\%) in the feed water, $\mathrm{kg} / \mathrm{m}^{3}$, sufficient to ensure $90 \%$ stabilization of $\mathrm{CW}$ on the number of the month.

Note that you can correct the stability of $\mathrm{CW}$ by adjusting the degree of concentration of salts in $\mathrm{CW}$, or the amount of blow. In this case, under the conditions of the invariance of $\mathrm{C}_{\mathrm{Ca}}(\mathrm{t})$ and $\mathrm{k}_{\mathrm{Ca}}(\mathrm{t})$ $=\mathrm{C}_{\mathrm{Ca}}(\mathrm{t}) / \mathrm{C}_{\mathrm{Ca} 0}(\mathrm{t})$, we obtain from (6) and condition $\mathrm{G}_{\mathrm{ev}}=$ Const the expression for calculating the blow, which increases the degree of stability from $\operatorname{StI}(\mathrm{t})$ to maxStI,

$$
\mathrm{G}_{\mathrm{b}}^{\mathrm{m}} / \mathrm{G}_{\mathrm{b}}=\frac{\operatorname{maxStI}}{\mathrm{StI}}\left(\mathrm{k}_{\mathrm{Ca}}-\mathrm{StI}\right) /\left(\mathrm{k}_{\mathrm{Ca}}-\operatorname{maxStI}\right)
$$

$\mathrm{G}_{\mathrm{b}}{ }^{\mathrm{m}}, \mathrm{G}_{\mathrm{b}}$ - blow woter discharge corresponding to the mode of operation of CCS with maxStI and with the current one.

Using the data of Fig.2, you can get the dependence of the blow on the number of the month similar to Fig.5. For a specific case: $\operatorname{maxStI}=0.9, \mathrm{StI}=0.7, \mathrm{k}_{\mathrm{Ca}}=1.8$, we obtain $\mathrm{G}_{\mathrm{b}}{ }^{\mathrm{m}} / \mathrm{G}_{\mathrm{b}}=1.57$, i.e. the blow must be increased by $57 \%$.

\section{Conclusions}

1. The main component of salt deposits in CCS is calcium carbonate. Magnesite is practically not available in the deposits due to its high solubility compared to calcium carbonate. $\mathrm{Mg}^{2+}$ ions in $\mathrm{CW}$ behave like chlorides being accumulated during the evaporation of $\mathrm{CW}$.

2. The method for quantitative assessment of the stability of $\mathrm{CW}$ as for carbonate deposits is suggested. On the example of data analysis on the quality of $\mathrm{CW}$ of one of the power plants of Ukraine, it is shown that the stability index for calcium carbonate adequately describes the state of CW and allows us to anticipate and develop measures necessary to ensure an acceptable level of stability of $\mathrm{CW}$ with regard to solid $\mathrm{CaCO}_{3}$ formation. 
3. The peculiarity of the method of determining the stability of CW against carbonate deposits is its simplicity, efficiency and the ability to create a database to automate the process of stabilization of CW and minimize deposits in the CCS.

4. Data on determining the degree of CW stability by calcium carbonate allows us to quickly develop and apply measures to minimize deposits, for example, by adjusting the concentration of inhibitors, acidification of $\mathrm{CW}$ or by regulating the blow of CCS.

5. The current methods of assessing the stability of water, based on the use of the concept of total water hardness, which are provided by Regulations, are not correct.

\section{References}

Alekin O.A. Fundamentals of Hydrochemistry. Hydrometizdat. Leningrad. 1970.- 444P.(in Russian).

Andronov V.A. Main dependences characterizing salt (material)and water balances of circulating cooling systems of industrial enterprises// Public utilities of the cities. 2004. Ed. 60. P. 151-155 (in Russian).

Dyatlova N. M. Complexons and complexonates of metals. / N. M. Dyatlova, V. Ya. Tyomkina, K. I. Popov. M.: Chemistry, 1988 . 544P (in Russian).

Gayevskii V.R., Kochmarskii V.Z. Efficiency increase of circulated cooling systems by minimizing calcium carbonate deposits. (Rivne, 2018) 154P. [ISBN 9789663273839] (in Ukrainian).

Guidelines for predicting the chemical composition and scale-forming properties of cooling water for power plants: RD 34.37.307-87. - Offic. ed. - Moscow: SPO Soyuztekhenergo: USSR Ministry of Energy, 1989. - 40P. (Guiding document of the USSR Ministry of Energy) (in Russian).

Kochmarskii V.Z., Gayevskii V.R., Tyshko N.L. Calcium carbonate crystallization from hydrocarbonate solutions. Ukr. J. Phys. 2017. V. 62. No 5. P. 382-391.

Kochmarskii V.Z., Kochmarskii O.V. Deposits in circulating systems of heat power plants. // Heat engineering. New challenges of the time. Bulletin of scientific papers. Editors: P. Omelianovskyi, V. Mysak. Lviv: Ukrainian technologies. 2009. P. 535-546 (in Ukrainian).

Kochmarskii V.Z., Pospelov D.N. The state of the problem of anti-flood water treatment in the USSR. - Kyiv: Knowledge. 1986. - P. 20 (in Russian).

Kucherenko D.I. Circulated water supply (Water cooling systems). Moscow: Strojizdat, 1980. - P. 169 (in Russian).

Pat. UA 114060. The method of determining stability index of circulated water in systems of technical water supply concerning the formation of solid $\mathrm{CaCO}_{3}$. Kochmarskii V.Z., Kochmarskii O.V. Bull. No 4 of 27.02.2017 (in Ukrainian).

Pat. UA 128018. The method of determining the dosage of the inhibitor necessary for the expected level of stability of the water circulating system and with regards to calcium carbonate. Kochmarskii V.Z., Kochmarskii O.V. Bull. No . No 16 of 27.08. 2018 (in Ukrainian). 
Shabalin A.F. Circulated water supply of industrial enterprises. Moscow: Publ. House on constructions. 1972. - P. 296(in Russian).

State Building Code (SBC) V.2.5-74: 2013. External networks and facilities. Basic design points (in Ukrainian).

Received 10.08.2020

Revised 28.09.2020

Accepted 30.09.2020

\title{
КОНТРОЛЬ СТАБІЛЬНОСТІ ОХОЛОДНОЇ ВОДИ ЩОДО КАРБОНАТНИХ ВІДКЛАДЕНЬ
}

\author{
В. 3. Кочмарський
}

Фізико-технологічної лабораторії водних систем Національного університету водного господарства і природокористування

Corresponding author: v.z.kochmarskii@nuwm.edu.ua

\section{Реферат}

На підставі даних аналізу відкладень на конденсаторах 22 електростанцій показано, що основним компонентом відкладень є карбонат кальцію. Магнезит у відкладеннях практично відсутній. Іони $\mathrm{Mg}^{2+}$ в оборотній воді ведуть себе подібно до хлоридів, концентруючись при випарюванні. Звертаємо увагу на те, що існуючі методики визначення стабільності охолодної води (ОВ) дають лише якісну інформацію про іiі стабільність. Вони грунтуються на використанні загальної жорсткості і дають завідомо некоректні дані про стабільність. Обговорюється методика кількісного визначення ступеня стабільності ОВ, що грунтується на вимірюваннях концентрацій іонів $\mathrm{Ca}^{2+}$ в ОВ та у воді підживлення і визначенні ступеня концентрування солей в ОВ. На підставі цих параметрів розраховують індекс стабільності OB. Маючи поточну величину індексу стабільності можна оперативно розробляти чи корегувати заходи щодо забезпечення потрібного рівня стабільності ОВ, наприклад, визначати величину підкислення чи продувки оборотної системи охолодження, достатньої для досягнення заданого ступеня стабільності.

Ключові слова: охолодна вода; відкладення; індекс стабільності; карбонат кальиію; корекиія стабільності. 